\title{
ENTPD1 wt Allele
}

National Cancer Institute

\section{Source}

National Cancer Institute. ENTPD1 wt Allele. NCI Thesaurus. Code C113580.

Human ENTPD1 wild-type allele is located in the vicinity of 10q24.1 and is approximately $165 \mathrm{~kb}$ in length. This allele, which encodes ectonucleoside triphosphate diphosphohydrolase 1 protein, plays a role in modulating hemostasis and thrombotic reactions. 